\title{
O LIVRO ANTES DO LIVRO: OS DISCURSOS LAUDATÓRIOS COMO EXÓRDIO DAS ANTOLOGIAS POÉTICAS SEISCENTISTAS
}

\author{
Maria do Socorro Fernandes de Carvalho (UFPI)
}

RESUMO: Os discursos preambulares compõem a adequação do livro, evidenciando o gênero da obra. Funcionam como exórdio, pois captam a disposição do público. Na poesia e na tratadística do Seiscentos, prólogos, cartas ao leitor, licenças, privilégios, dedicatórias, discursos encomiásticos e títulos promovem boa disposição e atenção no leitor ou ouvinte, promovendo valor e autoridade

PALAVRAS-CHAVE: prólogos; licenças; poesia; retórica; agudeza.

A prática livresca do Seiscentos revela a rica composição dos discursos preambulares. Os livros editados na península Ibérica neste período possuem um conjunto de discursos que antecedem - chegando mesmo a sobrepujar em importância - a obra do autor em publicação. Tais discursos, dispostos antes do livro propriamente dito, embora variáveis na forma, são retoricamente regrados na medida em que, especificados pelo uso, testemunham não apenas a exposição pública da obra, mas também o ato de sua publicação, seus efeitos sobre os leitores e as circunstâncias em que está sendo publicada. Trata-se de discursos breves, cartas, chancelas e poemas, pequenos textos de apresentação que, com o objetivo de angariar disposição afetiva para a obra, promovem (ou articulam) no registro impresso a recepção favorável que por vezes já existe em função da circulação manuscrita, oral ou impressa dos poemas. É o caso, entre muitos outros, do soneto que Manoel Faria e Sousa escreve para a reedição do livro Várias Poesias de Paulo Gonçalves de Andrade, em Coimbra, no ano de 1658, poema que obtém como resposta um segundo soneto, também publicado na sequiência do mesmo livro:

Tão altamente, ó Paulo engenho, \& arte, No acento teu gentil se remontavam, Que nenhum termo grande me deixaram, Para que a ti sem ti possa louvar-te. A imitar desse plectro a menor parte Desejos de aplaudir-te me inflamaram, E de o não conseguir se desculparam Com que era competir-te ou imitar-te. Tu só te louva a ti que para tanto Licenciando-te estão nossas invejas, Que elogios te hão de ser mais numerosos 
Logra por glória em nosso mudo espanto,

Que quando culpa de invejosos sejas,

Serás desculpa ufana de invejosos.

\section{Resposta}

Ya que me falta la que activa pudo

Mover las peñas, citara de Orfeo,

La suavidad que en estos versos leo,

Porque la vòz no canse, alabo mudo,

Obligame lo mismo de que dudo

A celebrar las partes, que no veo,

Venero lo que ignoro, y a mi empleo,

No con los passos, con el alma acudo.

Que el alma en tanto bien escrupulosa,

En vuestro entendimento se affigura

Bastante causa para ser dichosa.

Mas si enseñais del alma la hermosura

Como, occasion, en alma tan hermosa,

Dais al amor, negais a la ventura.

Os discursos dos prólogos e as cartas ao leitor, as licenças do paço, do ordinário e do santo ofício, os privilégios, as dedicatórias, as apresentações, os discursos encomiásticos e os títulos, todo este conjunto tem ação retórica similar à do exórdio, parte da composição definida na Retóricaaristotélica como o início do discurso, que predispõe e prepara o espírito do público, dando "o tom” da composição (livro III, capítulo 14, 1414b20-1415a7). Estamos, portanto, no domínio da disposição retórica, e a idéia é que, no livro seiscentista, mormente no livro impresso, a disposição desses discursos antes da obra interfere na constituição de seu decoro perante a opinião do público, compondo em parte sua autoridade.

A composição preambular é índice elegante do conhecimento e uso da língua cultivada no ócio dos homens discretos, e indica domínio das formas de representação das virtudes civis e políticas. Do ponto de vista discursivo, especificamente os prólogos, discursos laudatórios e dedicatórias têm a mesma finalidade do exórdio, qual seja, conquistar o interesse e a benevolência do leitor, exibindo por antecipação a causa final do discurso que se segue, por meio de fórmulas de modéstia. Para isso, articulam o antigo preceito da captatio benevolentiae, ou conquista da simpatia, atenção e docilidade do público. A Retórica ad Herennium prescreveu minuciosa articulação entre certos artifícios de linguagem e efeitos de captação ou reversão de afetos do público (livro I, 4-11). Como a poesia é gênero associado ao epidítico, convém precisamente o preceito aristotélico de que o proêmio "dá o tom" do discurso poético, podendo ter ou 
CARVALHO, M. S. F. O livro antes do livro: os discursos laudatórios como exórdio das antologias poéticas seiscentistas

não com este relação temática e formal. Tanto assim é que os discursos elogiosos de apresentação dos poemas, dedicatórias ao mecenas/senhor, elogios, e mesmo prólogos, podem ser compostos em versos. Quintiliano enfatiza justamente a liberdade exordial que Aristóteles predica ao gênero demonstrativo (III, 8, 8-9).

No século XVII, a preceptiva do poema épico normatiza a disposição de suas partes acionando a mesma precisão da épica antiga, embora também afaste-se dela em alguns particulares. Para Manuel Pires de Almeida, as partes que formam "o corpo" do poema heróico chamam-se "Prólogo, Proposição, Invocação, Dedicação, Narração. Proposição é o lugar primeiro da obra, em que propõe o poeta o que intenta cantar nela: esta seja breve, e clara, possível” (8). A condição de brevidade estende-se igualmente à invocação das deidades e musas da poesia; quanto à dedicatória épica, deve estar fora da obra,

pelo cheiro que tem de adulação, de que o Poeta heróico há de estar mui livre, porque só a virtude sem outro interesse o há de mover a cantar, para persuadir perfeitamente à imitação, o que não se faz com a lisonja, pois nasce dela grandíssimo aborrecimento aos ouvintes, e terem por mentiroso o Poema, dano mui considerável para o poeta. (ALMEIDA 8).

Vê-se, portanto, que Pires de Almeida reitera as finalidades da poesia heróica, fundamentalmente o cantar a virtude heróica para mover e persuadir, pela isenção de interesses impróprios e exteriores ao discurso, vícios que produzem o tédio - contra o qual operam todos os artifícios proemiais - e danificam o caráter do orador. Os gêneros líricos imitam a qualidade da disposição exordial do poema épico, e afastam-se de seus vícios, reservando, como em todos os aspectos intrínsecos à lírica, a finalidade nuclear deste gênero: o deleite do ouvinte ou leitor pelo canto elogioso ou maledicente da matéria do poema. Artifício comum aos livros desse período é o autor apresentar-se por meio de uma persona retoricamente construída, que se mostra nos proêmios como imitador sofrível da autoridade dos modelos imitados por afetação de modéstia. Por esse artifício de humildade fingida, o autor inicia o processo de conquista do interesse do leitor desde antes da obra. Na lírica, esse exercício de "abaixamento" da autoria eleva a matéria do poema, pois a persona nunca representa-se à altura de glosar o que é 
CARVALHO, M. S. F. O livro antes do livro: os discursos laudatórios como exórdio das antologias poéticas seiscentistas

proposto, para o quê solicita o signo de autoridade do mecenas, patrono ou senhor a quem dedica a obra. Um efeito desse artifício é a aproximação, por imitação, da matéria lírica à matéria dos gêneros elevados, heróica por convenção e enobrecida pelas partes, lugares e virtudes poéticas próprias, como ensina Pires de Almeida. Mas não apenas obras poéticas aderem a essas conveniências, também a tratadística e, no geral, obras preceptivas compõem o decoro dos discursos de apresentação. É o caso ilustrativo da "dedicatória" do tratado sobre agudeza poética que o teólogo bolonhês Matteo Peregrini publica em 1639, com o título de Delle Acutezze:

\section{Ao Ilustríssimo Senhor e Patrono Honorabilíssimo,}

o Senhor Filippo Adorno Permito-me ilustrar a fronte de meu presente livro com o esplendor do nome de V. S. Ilustríssima, desejoso de manifestar-me devoto de sua pessoa e pertencente à sua casa em todo o mundo e por todos os séculos. Não que a obra, assim tão débil, possa, por si própria, garantir imortalidade, mas porque, do haver nela impresso a nobilíssima marca do sangue Adorno, posso venturosamente essa imortalidade esperar. E facilmente, porque, assim [a obra] virá a participar dos raios desta gloriosa linhagem, a qual, por haver socorrido tantas vezes a pátria Ligúria envolta em perigosas ondas, e tendo produzido tantos heróis na posse do cetro real, servindo também hoje, V. S. Ilustríssima, por semelhante gloria, ao futuro sua generosíssima semente, nos anais da fama viverá meritoriamente imortal. (5, tradução ad hoc)

São noções como as de autoridade, proveito, emulação e concórdia que fundamentam esses discursos. Seu efeito é demonstrar a adaptação do gênero ao estilo e matéria do discurso poético que os segue, especificando com isso, eles mesmos, um uso aprovado do discurso que retoricamente já iniciaram. Isso ocorre porque antologias poéticas, impressas ou manuscritas, individuais ou coletivas eram compreendidas como lugar por excelência das formas próprias de dizer do cortesão, o homem livre capaz de expressarse nas artes com agudeza e prudência. Os discursos preambulares compunham o elogio do engenho do autor, segundo uma concepção do livro como antologia de preciosidades ou "engenhos" humanos, lugar de recolhimento das imitações poéticas dos melhores poetas, cestas de flores.

Dessas partes do discurso, os prólogos desempenham importante papel. São, de modo geral, justificativas que o autor ou uma persona qualificada dá à edição pública da obra. Escritos em forma de pequenas cartas ao leitor, alegam como causa final da publicação dos livros de poesia o proveito pela difusão da doutrina, a glorificação da honra do autor 
CARVALHO, M. S. F. O livro antes do livro: os discursos laudatórios como exórdio das antologias poéticas seiscentistas

ou a oferta de deleite pela divulgação dada à obra, e não raro acusam as três finalidades. É pela rubrica de autoridade apresentada nos prólogos dos livros que o leitor reconhece a qualidade do engenho de quem os concebeu, como uma espécie de filiação ao patrimônio das artes, seus modelos e modos de apropriação das fontes, a que o autor da obra é submetido. O fundamento de discrição que a convenção das letras arvora à autoridade dos engenhos, tidos como agudos, doutos e possivelmente modelares, é alimentado pelo efeito precisamente retórico de ostentação de valor pela modéstia afetada, aspecto paradoxal apenas na aparência. Neste lugar pró-logos, a benevolência e disposição do leitor são buscadas num meio-termo arriscado entre o desejo pedante do autor em "grangear aplausos" e o sentido de missão, devoção ou apenas serviço que o autor demonstra, pela expressão do talento que a publicação da obra aporta. Para refutar possíveis acusações de presunção, o autor ou editor não recorrem a nenhuma "artillería de argumentos", como diz Francisco Cascales, mas submetem-se modestamente ao juízo do leitor, este sim certamente agudo, douto e perspicaz, segundo a "modelização retórico-poética" que constitui a interlocução discreta do discurso de agudeza, concebido por um "ato de entendimento", nas palavras de Baltasar Gracián, que necessita sempre do também entendimento do leitor ou ouvinte, igual discreto capaz de compreender a excelência desses escritos. $O$ poeta coloca-se assim num lugar fingido de humildade e devoção que mais revela, por efeito, a autoridade de sua rubrica e o decoro da obra que sabe representar. Quanto mais modestamente o engenho do autor promover sua obra e a si, mais inteirado revela-se das convenções de cortesia, que é também política, além de ser letrada. Por conta disso, afirma Domingos Carneiro, editor das Poesias Váriasde André Nunes da Silva, publicadas em 1671 em Lisboa: "Leitor Amigo, ou Inimigo, que tudo podes ser, aqui te ofereço estas Poesias (...) Se te forem aceitas, livrarei no teu agrado o lucro do meu desvelo, \& se molestas, na tua mão tens o remédio, cerrando o livro." É desse lugar afetado de modéstia que surgem os numerosos vocativos ao leitor que, de nomeadamente "amigo", pode ser também "inimigo", como dito acima, ou "leitor meu, bem ou mal affecto", "prudente y Christiano", "benigno y discreto", "religioso, capucho, leigo, conimbricense, homem sem sobrescrito, pelão e de meia tigela" etc.

A preceptiva poética toma para si um leitor diferenciado pelo ofício a que a arte da poesia serve, pelo que institui no leitor "amigo poeta" o destinatário virtual de obras 
CARVALHO, M. S. F. O livro antes do livro: os discursos laudatórios como exórdio das antologias poéticas seiscentistas

nascidas não da vaidade do seu inventor, mas da necessidade de normatização dos preceitos poéticos. Esse particular revela um interesse específico pelo que indica sobre a concepção coetânea de poesia, tida como arte "porque, según Aristóteles, el arte es aquella que da preceptos y enseña los caminos para no errar en aquello que professamos", afirma Cascales, o autor das Tablas Poéticas, no prólogo em que refuta poetas "guiados mais pela natureza que pela arte", oferecendo-lhes sua obra como abrigo na norma: "Y mientras no tuvieres a la mano otros maestros de poesía, al mar tempestuoso arrojo estas Tablas Poéticas; quando te fueres anegando en el golfo de la dudosa confusión, arrímate a ellas, y por ventura saldrás a la orilla salvo y libre de la tormenta."

Prólogos são, de costume, escritos em prosa, mas o editor do Ecco primeiro do Postilhão de Apolo, uma antologia setecentista da poesia de agudeza elaborada em Portugal entre os séculos XVII e XVIII, por anagrama Joseph Maregelo de Osan, concebe em versos decassílabos a evocação ao leitor de sua coletânea:

Parece lei, e passa a ser costume,

Que em reverência de qualquer volume,

Que com parto jucundo

Sai do ventre do prelo à luz do mundo,

E na berlina, que lhe doura o ferro,

Coberta de carneira, ou de bezerro,

Corre sem descançar por vários modos,

Servindo-lhes de pés as mãos de todos;

Que um Prólogo adiante

Traga em lugar de archote bem flamante,

Que lhe venha aclarando

O quis, quibus, e quid, quomodo, e quando:

Inda que esteja claro quanto encerra,

E tenha o livro o fruto à flor da terra.

Assim como os prólogos, as dedicatórias consideram determinada convenção que atende a normas de pedido ou reconhecimento de mecenato. Estas formas operam o mesmo mecanismo de representação de discrição pela modéstia retoricamente forjada na submissão da obra e do autor à necessidade de honra e fama da liberalidade, glória e valor do senhor que as abriga, artifício sintetizado, por exemplo, na seguinte sentença de Francisco Cascales: "al tanto que la insufficiencia no emprende, se arroja la voluntad." Com essas prerrogativas, as dedicatórias podem ser elaboradas por terceiros, os editores em alguns casos, como as Várias Poesias de Paulo Gonçalves de Andrade dedicadas a 
CARVALHO, M. S. F. 0 livro antes do livro: os discursos laudatórios como exórdio das antologias poéticas seiscentistas

Francisco de Faria Severim pelo impressor da obra que, solícito, declara ao Chantre da Sé de Évora: "Esta impressão ilustrada com o raio de tanta luz logrará eterno seu luzimento, \& eu trocarei a liberdade de meu afeto bem empregado pelos grilhões de uma obrigação eternizada."

Dedicatórias podem também ser escritas em verso, como a Epístola dedicatoria ao Excellentissimo Principe o Senhor D. Duarte, pelo licenciado Manoel da Veiga, no livro Laura de Anfriso, de 1626:

Vede aquela paterna Magestade, De tão doce brandura acompanhada: Bebei nela Senhor a humanidade. E esta Musa que vai mal cultivada, Alhea de conceitos, \& artifício, Seja em vossa grandeza agasalhada. Aqui vos canta o rústico exercício, Dai vossa mam Real aos meus Pastores, Que o cantar-vos tomarão por ofício. Outros tempos virão, dias maiores, Quando na tuba clara, e sonorosa Vos possa oferecer versos melhores. (2)

Mais comumente são escritas em prosa, caso da dedicatória do livro de Alonso López Pinciano, espanhol autor da Filosofia Antiga Poética, de 1596, em que faz uma ressalva ao conde a quem dedicara a obra, por considerar alguns trechos impróprios "às orelhas" do nobre senhor:

Otrosí: suplico a V.S. si algún dia hiziere a esta obra digna de sus oydos, los abstenga de la epístola nona y especialmente del fragmento quarto della, cuya materia es ridícula y más conveniente a orejas populares y cómicas que no a las patricias y trágicas, quales ser deven las de los Princípes y grandes señores y quales son las de V.S. etc. (tomo I, p.6)

As dedicatórias dos livros seiscentistas são hoje lidas como sínteses teóricas das letras daquele tempo, como aliás o conjunto desses discursos preambulares, em que a poesia era concebida segundo o conceito da imitação dos melhores autores. Não obstante ser lugar de aplausos, as dedicatórias primam pela brevidade do discurso, conforme preceito destacado por Pires de Almeida (antes referido), mas nunca por desmerecimento da personagem que ilustram, cuja magnificência é impossível de ser 
CARVALHO, M. S. F. O livro antes do livro: os discursos laudatórios como exórdio das antologias poéticas seiscentistas

acomodada nas poucas linhas que a convenção dispensa à dedicatória, conforme reclama Manuel Botelho de Oliveira, numa metáfora marinha, quanto à exigüidade do "papel epilogado", pois "nele não cabe a multiplicidade de tantos títulos, quanto as acreditam, seria temeridade querer recopilar um mar imenso em tão limitada concha, e copiar figura tão agigantada em um quadro tão pequeno" (1953: 8). A propósito da dedicatória de sua antologia Música do Parnasso, a reconstituição teórica da lírica, muito significativa para a crítica hodierna, é bastante evidenciada pelo percurso normativo que o autor desenha ao considerar as fontes e modelos da imitação que se segue nos quatro livros de sua obra. Botelho de Oliveira arrola artes e autores gregos, e após estes, italianos e ibéricos - antigos e modernos - e se estende à conjuntura americana colonial, cujas poéticas compuseram o patrimônio das artes de que se serve como imitador:

Nesta América, [as Musas] quiseram também passar-se a este empório, aonde como a doçura do açúcar é tão simpática com a suavidade do seu canto, acharam muitos engenhos, que imitando aos poetas de Itália, e Espanha, se aplicassem a tão discreto entretenimento. (1953: 3)

Outro lugar de interesse são as licenças, aprovações exigidas a todo livro, fosse arte retórica ou encômio régio. Havia três tipos de leitura prévia: a primeira dizia respeito à licença do "Santo Ofício", censura que cuidava da difusão das verdades católicas contra o anúncio de idéias que portassem insegurança aos dogmas teologais. Havia também as licenças do Paço e do Ordinário, que prezavam o acolhimento das leis civis contra pressupostos que fossem danosos à república, ou a valores eclesiásticos e morais. As licenças eram providas por secretários, notários, licenciados, freis, padres, inquisidores, validos e conselheiros, enfim, por homens de notório saber na sociedade seiscentista. Algumas vezes era referido também o valor da taxação do livro. Mesmo licenças aprovativas atestavam, por vezes, restrições. Trechos de livros eram cortados, ou exigiam-se explicações ou alterações ao autor. Caso do mesmo Poesias Várias de André Nunes da Silva, livro ao qual os censores exigiram uma alteração na disposição das poesias, de modo a se "apartarem das profanas, as sagradas". Casos muito interessantes ocorrem quando o censor empenha-se em demonstrar a razão de seu parecer. Exemplo conhecido encontra-se em Os Lusíadas, épico cuja licença de publicação foi provida 
CARVALHO, M. S. F. O livro antes do livro: os discursos laudatórios como exórdio das antologias poéticas seiscentistas

pelo frei Bartolomeu Ferreira, com a condição de que o leitor deveria estar atento para o fato de que os deuses pagãos ali citados eram ornatos que desempenhavam a função de alegorias poéticas, mas que eram, fora da ficção poética, demônios dos gentios, sem conhecimento da luz divina do cristianismo, segundo ele. No século XVII, licenças continuam a ser dadas com base no mesmo pressuposto da licentia poética; os argumentos dos censores têm por fundamentos o uso, a autoridade da rubrica e as normas do gênero do discurso. Sob argumento semelhante ao fornecido a Camões, concede licença de impressão o censor das Rimas Várias de Antonio Álvares Soares, em 1628, atualizando tacitamente a Arte Poética de Horácio:

porque o Autor trata seus conceptos e pensamentos com muita honestidade, sou de parecer que se imprimam, porque ainda que atribua as criaturas divindade e adoração, não deve prejudicar o seu intento (...) porque isto são encarecimentos de Poetas e mui ordinário modo de falar, assim em os antigos, como nos modernos, e assim parece se lhe não deve negar a licença que a outros se concedeu.

Especialmente ricas para o conhecimento do conceito de poesia nesse período são as licenças dadas às Luzes da Poesia, arte poética de Manoel da Fonseca Borralho, publicada em 1724 em Lisboa. A primeira delas tem como "Qualificador do Santo Ofício" o clérico Rafael Bluteau, que justifica a publicação do livro de Borralho, "legislador do Parnaso", em consideração da matéria:

Poesia, Arte nobilíssima, a qual, inda que costume nascer com os sujeitos, que a exercitam, depende de muitas notícias, que ordinariamente sem Mestre se ignoram, e ignoradas ocasionam partes informes, Antípodas das Musas, e escândalos de Apolo. Sendo, pois a Poesia, como aqueles frutos cuja mediania no gosto é vício, e só prestam quando excelentes.

A segunda licença faz uma reflexão sobre o registro escrito das artes preceptivas e os efeitos desses atos de publicação sobre a convenção das letras:

sempre a arte conduz muito para aperfeiçoar e dar lustre ao gênio, e para emendar, ou dar firmeza ao uso. A escritura, durável cópia das palavras, serve de consagrar à eternidade os conceitos, que por humanos têm a triste pensão de transitórios: mas servir- 
CARVALHO, M. S. F. O livro antes do livro: os discursos laudatórios como exórdio das antologias poéticas seiscentistas

lhes-a de eterno descrédito se for menos acertada, como a imagem mal feita a um fermoso original. (página das licenças)

Outros discursos preambulares constam nos livros seiscentistas, embora sem formas definidas, como os privilégios, as apresentações e os discursos encomiásticos. Os privilégios são licenças mais amplas, com direitos de impressão e venda das obras estendidos. Todos esses discursos primam pela brevidade, pois existem para compor a adequação do livro que recomendam, evidenciando o gênero e a eminência da obra, conforme vimos no preceito e podemos comprovar pela introdução brevíssima dos Poemas Lusitanos de António Ferreira, publicados em 1598:

Aos bons ingenhos

A vós só canto, espritos bem nascidos,

A vós, e às Musas ofereço a lira,

Ao Amor meus ais, e meus gemidos,

Compostos do seu fogo, e da sua ira.

Em vossos peitos sãos, limpos ouvidos,

Caiam meus versos, quais me Febo inspira.

Eu desta glória só fico contente,

Que a minha terra amei, e a minha gente.

(2000: 47)

No entanto, essa noção não impede que, por concessão da brevidade, se façam presentes antes da obra discursos laudatórios mais longos, que contêm juízo e interpretação do decoro do poema, servindo-lhe como "compêndio das finezas e primores", pelo que este do comum dos poemas afasta-se. Exemplo perfeito temos no Discurso Poético de Manoel de Galhegos, apologia do livro de Gabriel Pereira de Castro, Ulisseia ou Lisboa Edificada, Poema Heróico, na edição de 1636, do qual extraí os seguintes trechos:

Usa [o poeta] felicemente das três figuras de que mais necessita a textura, que são,Parasceue, Analogia e Teliotis, idest, preparatório, proporção, perfeição. (...) A claridade, ou a enargeia (que é a evidência no dizer) observa tudo quanto Hermógenes amoesta na palavra Saphinia [saphéneia]: a grandeza do estilo (...) A brevidade no explicar a sentença é soberana: tarda mui pouco em dar forma ao conceito, que é o que encomenda Hermógenes na palavra Gorgotis. Que val o mesmo que Pressa.

Os títulos dos livros seiscentistas remetem, de modo geral, ao deleite que a obra deverá proporcionar ao leitor ou ao ouvinte, por isso costumam ser enunciados sob o signo do 
CARVALHO, M. S. F. O livro antes do livro: os discursos laudatórios como exórdio das antologias poéticas seiscentistas

gozo: deleitações, passatempos honestos, triunfos, cancioneiros, divertimentos, entretenimento curioso e, sobretudo flores, com vantajosa rede de sinônimos: florilégios, antologias, ramalhetes, jardins. Os títulos chamam atenção também pela extensão que por vezes possuem. É o caso da edição revista e aumentada da antologia editada por Osan, já citada, vinda a público entre 1761 e 1762, que recebe o curioso título de:

Ecos que o Clarim da Fama Dá: Postilhão de Apolo montado no pégaso, girando o universo para divulgar ao orbe literário as peregrinas flores da poesia portuguesa, com que vistosamente se esmaltam os jardins das Musas do Parnaso. Academia universal, em a qual se recolhem os cristais mais puros, que os famigerados engenhos lusitanos beberam na fonte de Hipocrene, Helicona e Aganipe.

Portanto, a idéia de que os discursos preambulares ajudam a compor a adequação do livro, evidenciando desde o princípio o gênero e natureza dos discursos presentes no interior da obra encontra respaldo em vários elementos compositivos. Em primeiro lugar, esses discursos possuem normatização retórica; são com efeito artifícios retóricos com fins muito específicos e concorrem, no conjunto, para o decoro da obra que iniciam, no que se assemelham ao exórdio, parte do discurso prevista nas retóricas mais antigas como prenunciador do gênero do discurso que inicia. Nos livros de poesia e na tratadística das artes nos anos seiscentos, a prática da composição preambular tem como finalidade captar a boa disposição e atenção do leitor ou ouvinte. A concepção do livro como antologia de preciosidades ou "engenhos" humanos no ambiente de corte absolutista peninsular adere, portanto, à concepção de poesia como um ato de agudeza intelectual, certa capacidade intelectual de formular analogias, matéria do elogio exordial. É para promover fama, valor e autoridade que são compostos prólogos e cartas ao leitor, licenças do paço, do ordinário e do santo ofício, privilégios, dedicatórias, apresentações, discursos encomiásticos e títulos. Os discursos dispostos antes do livro revelam também a prática discreta de publicação de livros impressos como dispositivo político e social de distinção, porque indicavam precisamente que seu autor possuía elevação nas letras, tratando-se assim de homem douto, treinado nas artes civilizatórias mais prestigiadas: retóricas, filosóficas, gramaticais, poéticas, nomeadamente as artes dos antigos gregos e romanos, e algumas autoridades da era cristã, conforme atestam as 
CARVALHO, M. S. F. O livro antes do livro: os discursos laudatórios como exórdio das antologias poéticas seiscentistas

licenças.

\section{OBRAS CITADAS:}

ALMEIDA, Manuel Pires de. Discurso sobre o Poema Heróico. Lisboa. Manuscrito do Arquivo Nacional da Torre do Tombo.

ANDRADE, Paulo Gonçalves de. Varias poesias. Coimbra: Officina de Manoel Dias Impressor da Universidade, 1658.

ARISTÓTELES. 1998. Retórica. Trad. e notas por Miguel Alexandre Júnior, Paulo Farmhouse Alberto e Abel do Nascimento Pena. Lisboa: Imprensa Nacional - Casa da Moeda.

BORRALHO, Manoel da Fonseca. Luzes da Poesia descubertas no Oriente de Apollo nos influxos das muzas, divididas em tres Luzes essenciaes [...]. Lisboa: Officina de Felippe de Sousa Villela, 1724.

CAMÕES, Luís de. 1988. Obra Completa. Rio de Janeiro: Nova Aguilar.

CASCALES, Francisco. 1975. Tablas Poeticas. En Murcia, por Luis Beros, 1617. Madrid: Espasa-Calpe.

FERREIRA, Antonio. 2000. Poemas Lusitanos (1598). Ed T. F. EARLE. Lisboa: Fund. Calouste Gulbenkian, 2000.

GRACIÁN, Baltasar. 1987. Agudeza y Arte de Ingenio. (1648). Ed. Evaristo C. CALDERON. Madrid: Clásicos Castalia.

HORÁCIO. 1981. Arte Poética. A poética clássica: Aristóteles, Horácio, Longino. São Paulo: Cultrix.

OLIVEIRA, Manuel Botelho de. 1953. Música do Parnasso (1705). Antenor Nascentes. (org.). Rio de Janeiro: MEC/Instituto Nacional do Livro.

OSAN, Joseph Maregelo, ed. 1761-62. Eccos que o Clarim da Fama dá : Postilhão de Apollo [...] (1762). Lisboa: Offic. de Francisco Borges de Souza. 2 tomos.

QUINTILIANO. 1996. Institutio Oratoria. 1ª ed.: 1921. Harvard, Loeb classical library. (126). $4 \mathrm{t}$.

PEREGRINI, Matteo. 1997. Delle Acutezze. Torino: Edizioni Res.

PINCIANO, López. 1953. Philosophia Antigua Poetica (1596). Ed. A. C. Picazo. 3v. Madrid: Instituto Miguel de Cervantes. 
CARVALHO, M. S. F. O livro antes do livro: os discursos laudatórios como exórdio das antologias poéticas seiscentistas

Rhétorique à Herennius. 1997. Trad. Guy Achard. Paris: Les Belles Lettres.

SILVA, André Nunes da. 1671. Poesias várias. Recolhidas por Domingos Carneiro. Lisboa: Domingos Carneiro.

SOARES, Antonio Álvares. 1628. Rimas várias: primeira parte. Lisboa: Matheus Pinheiro.

VEIGA, Manoel da. 1628. Laura de Anfriso. Évora: Manoel Carvalho, impressor da Universidade. 